\title{
LEARNING HOW STUDENTS LEARN: A COMPARATIVE STUDY ON GRADUATED AND POST GRADUATED ENGINEERING STUDENTS
}

\author{
Fernando Castelló Sirvent ${ }^{1}$, Lourdes Canós Darós ${ }^{2}$ \\ ${ }^{1}$ ESIC Business \& Marketing School (SPAIN) \\ ${ }^{2}$ Universitat Politècnica de València (SPAIN)
}

\begin{abstract}
The behavior of students is different depending on their preferences regarding learning styles. Preferences are very important: active-reflective, sensing-intuitive, visual-verbal and sequential-global, determine their interest and motivation, as well as interaction with teachers and other students.

The evidence suggests that active students retain and understand information better and are willing to discuss it, explain it to other students and even apply it to real cases. Reflective students prefer to think individually, in silence. Sensitive students enjoy learning and intuitive students often prefer to discover hidden possibilities and relationships. Students of visual learning learn with flowcharts and images, even construct sketches and schemes, transforming verbal materials into visual representations. Sequential learners improve their comprehension in consecutive steps, from the discovery of the internal logic that connect them.

Following the Felder-Silverman Learning Styles Model (FSLSM), this study analyzes the preferences revealed by graduate and postgraduate students at the Universitat Politècnica de València (Spain). Within the framework established by the FSLSM, the Index of Learning Styles Questionnaire (ILS) developed by Felder and Soloman was presented to students of the Degree in Industrial Organization Engineering and the Master's Degree in Industrial Engineering.
\end{abstract}

This study analyzes both groups of students. The diversity of learning styles in the classroom should be taken into account by teachers to improve student performance in the learning process.

Keywords: learning styles; FSLSM; ILS; engineering; learning experience; labor market.

\section{INTRODUCTION}

Improving the quality of university education is articulated through the analysis of training processes. Learning is a central point of the European Higher Education Area (EHEA) in the integration of content with new methodologies; then, the focus of the analysis allows the achievement of competences by students [1]

In this sense, active participation in the classroom becomes a fundamental aspect [2] along with the use of new technologies [3], reaching far beyond the transmission of knowledge between lecturer and student, making much more important the own learning analysis [4].

Real and active participation of students is activated with the interaction and joint work between lecturers and students [5] and this is developed from the fit between the learning styles of students and the methodologies.

In the teaching-learning process, teaching is the part associated with the lecturer, while learning corresponds to the student [6]. Traditionally it has been understood that these two processes were isolated and that they should be treated individually, each with its characteristics and importance, but without any relationship or synergy between them. The current teaching practices, however, understand that both are the same process and that one cannot occur without the other, understanding these two activities not in isolation, but as a unique process.

In this context, as lecturers we usually experience a feeling of more intense affinity in one group than in another, more in one subject than in another. Possibly, if there is little fit between the lecturer and the students, the reason is that their learning styles are different. Ignorance of this fact can lead to a feeling of discomfort on both sides and the non-achievement of teaching-learning objectives. Knowing this situation, lecturers have the easy solution of adapting teaching strategies to the majority learning style of the group, in order to promote their virtues and guide their shortcomings [7]. It is important to create a learning environment in which students are able to mobilize their cognitive and behavioral 
abilities in the learning processes. [8]. By taking into account the learning styles of the students, it is possible both to assist the teacher in choosing the most appropriate teaching strategies for the activities to be developed in the learning environment, as well as to assist the individual student as far as possible [9].

Moreover, in the learning environment of each subject, lecturers have a learning style (usually stable over time) and students, which are usually different in each course that passes, others different or equal to the lecturer, which can result in one group predominant or in several and scattered groups. Learning styles are defined as a set of intellectual and personality characteristics that shape the way in which students perceive, interact and respond to learning situations [10]. The identification of learning styles can be done through the questionnaire proposed by Kolb [11] and the one proposed by Felder and Soloman that identifies eight learning styles based on the previous ones [12].

Although the use of learning styles has been criticized by some authors [13] in practice it has been confirmed as an effective tool for improving the quality of teaching in high education centres. Knowing how students learn allows lecturers to adapt their teaching activities and pedagogical practices and use resources tailored to the profiles of students [8].

In this sense, we must take into consideration the importance of participatory and cooperative teamwork [14] and its conditioning factors based on the preferences of learning styles revealed by the student.

In particular, Felder and Silverman [12] developed an analysis model for the existing connections between learning styles and university teaching (Felder-Silverman Learning Styles Model (FSLSM)), fixing 4 dimensions and 2 dichotomous styles for each dimension, defining levels of perception (sensitive-intuitive), input (visual-verbal), processing (active-reflective) and comprehension (sequential-global).

In a context in which collaborative work is placed at the center of the teaching methodology of Spanish universities [15], the way in which students show a mostly polarized position among themselves and the way in which the lecturer adapts his or her classroom activities can condition learning outcomes. This study compares the preferences revealed by graduate and postgraduate students at the Universitat Politècnica de València (Spain), within the framework established by the FSLSM and the Index of Learning Styles Questionnaire (ILS) developed by Felder and Soloman [16, 17].

\section{METHODOLOGY}

A questionnaire was provided with the ILS to Degree in Industrial Organization Engineering and Master's Degree in Industrial Engineering students, analysing their characterization and comparing differences between both groups of students.

The ILS is a survey instrument used to assess preferences in the four dimensions proposed by the FSLSM. The instrument was developed and validated by Richard M. Felder and Barbara A. Soloman (2005). The questionnaire has 44 double-choice questions. The configuration of the answers returns profiles in the continuum that represents each of the FSLSM dimensions (perception, representation, processing and comprehension), articulated by their corresponding dichotomies (sensitive-intuitive, visual-verbal, active-reflexive and sequential-global).

It is very important for the lecturer to know the positions in which students are located according to the questionnaire results. If a majority of students is in central positions, all kinds of training actions have better results. However, when the positions of the students are extreme, the teaching actions designed on the opposite extreme to their preference are in conflict to connect with the lecturer.

\section{RESULTS}

The frequency of distribution (table 2) of the results obtained for the ILS provided to the students (table 1) represents a characterization mainly centred on a vector, showing also some isolated cases whose learning vectors are diverse and must be attended in a differentiated way by the teaching staff and must be taken into account when designing teaching experiences. 
Table 1. Description

\begin{tabular}{c|c|c|c|c|c|c}
\hline \hline & \multicolumn{3}{|c|}{ N } & \multicolumn{3}{c}{ Age } \\
\hline & Total & Male & Female & Mean & Min & Max \\
\hline GIOI & 42 & 25 & 17 & 20,74 & 20 & 27 \\
\hline MUII & 50 & 36 & 14 & 23,92 & 22 & 29 \\
\hline \hline
\end{tabular}

Table 2. ILS results

\begin{tabular}{|c|c|c|c|c|c|c|c|c|c|c|c|c|c|c|c|c|c|c|c|c|c|c|}
\hline & \multicolumn{11}{|c|}{ ACTIVE } & \multicolumn{11}{|c|}{ REFLEXIVE } \\
\hline & 11 & 10 & 9 & 8 & 7 & 6 & 5 & 4 & 3 & 2 & 1 & 1 & 2 & 3 & 4 & 5 & 6 & 7 & 8 & 9 & 10 & 11 \\
\hline GIOI & & 1 & 2 & 3 & 2 & 3 & 5 & & 5 & & 7 & 7 & & 3 & & 4 & & & & & & \\
\hline MUII & & & 1 & & 2 & 2 & 8 & & 8 & & 8 & 10 & & 7 & & 3 & & 1 & & & & \\
\hline & \multicolumn{11}{|c|}{ SENSITIVE } & \multicolumn{11}{|c|}{ INTUITIVE } \\
\hline & 11 & 10 & 9 & 8 & 7 & 6 & 5 & 4 & 3 & 2 & 1 & 1 & 2 & 3 & 4 & 5 & 6 & 7 & 8 & 9 & 10 & 11 \\
\hline GIOI & & & & & & & 3 & & & 1 & 1 & 10 & & 1 & & 10 & 2 & 5 & 4 & 5 & & \\
\hline MUII & 1 & & & 1 & 2 & & 2 & & 2 & 1 & 1 & 9 & & 4 & 1 & 9 & 1 & 11 & & 5 & & \\
\hline & \multicolumn{11}{|c|}{ VISUAL } & \multicolumn{11}{|c|}{ VERBAL } \\
\hline & 11 & 10 & 9 & 8 & 7 & 6 & 5 & 4 & 3 & 2 & 1 & 1 & 2 & 3 & 4 & 5 & 6 & 7 & 8 & 9 & 10 & 11 \\
\hline GIOI & & & & & & & & & 2 & & & 1 & & 4 & 1 & 7 & & 9 & 1 & 8 & 3 & 6 \\
\hline MUII & & & & & & & & & 3 & & 3 & 4 & & 5 & & 10 & 1 & 12 & & 9 & & 3 \\
\hline & \multicolumn{11}{|c|}{ SEQUENTIAL } & \multicolumn{11}{|c|}{ GLOBAL } \\
\hline & 11 & 10 & 9 & 8 & 7 & 6 & 5 & 4 & 3 & 2 & 1 & 1 & 2 & 3 & 4 & 5 & 6 & 7 & 8 & 9 & 10 & 11 \\
\hline GIOI & & & & & 1 & & & & & & 6 & 2 & 1 & 8 & 1 & 6 & & 9 & 2 & 3 & & \\
\hline MUII & & & 2 & & 2 & & 3 & & & & 11 & 7 & & & 1 & 4 & & 5 & & 2 & & \\
\hline
\end{tabular}

Figure 1 shows the comparison between Degree in Industrial Organization Engineering (GIOI) and Master's Degree in Industrial Engineering students (MUII).

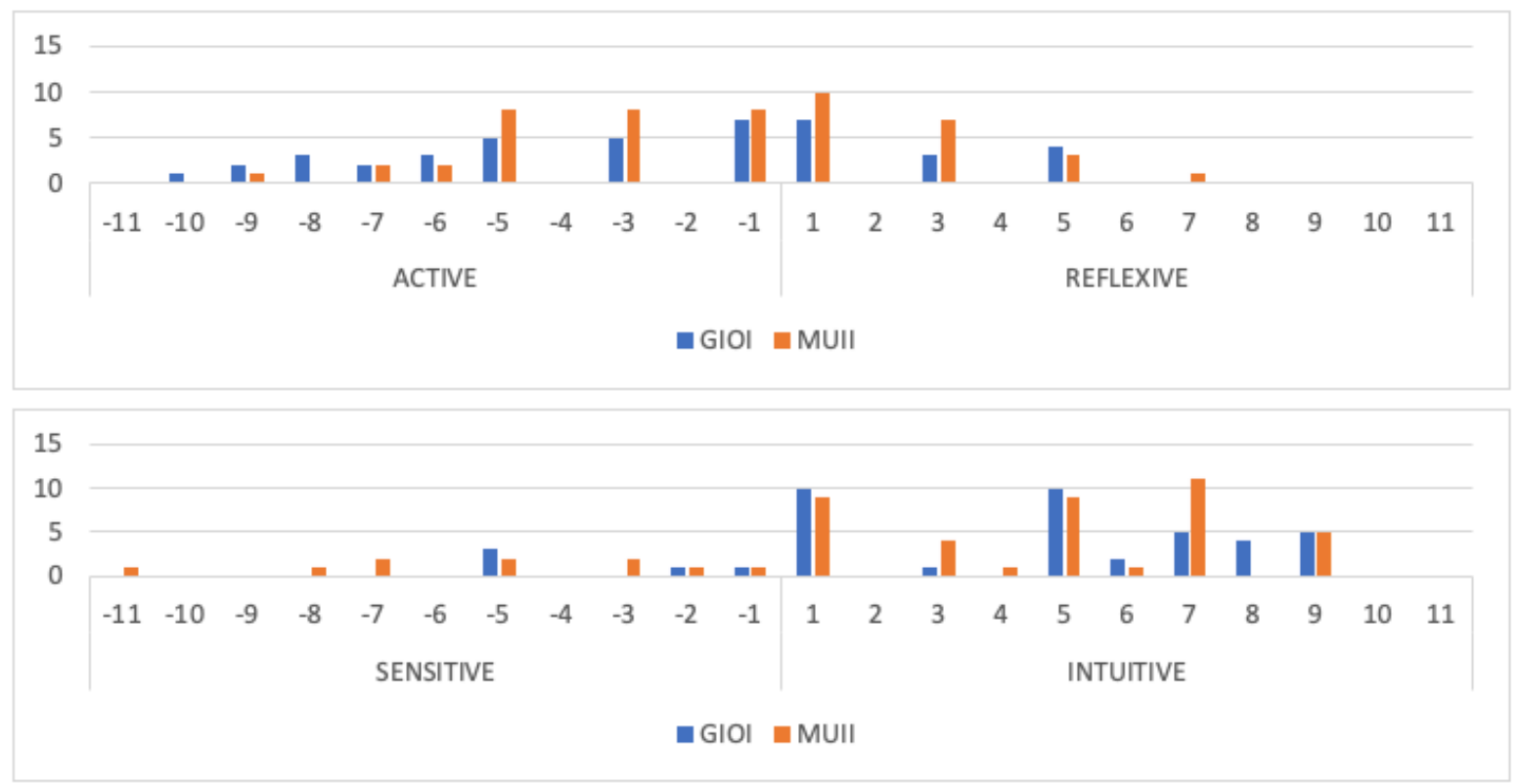




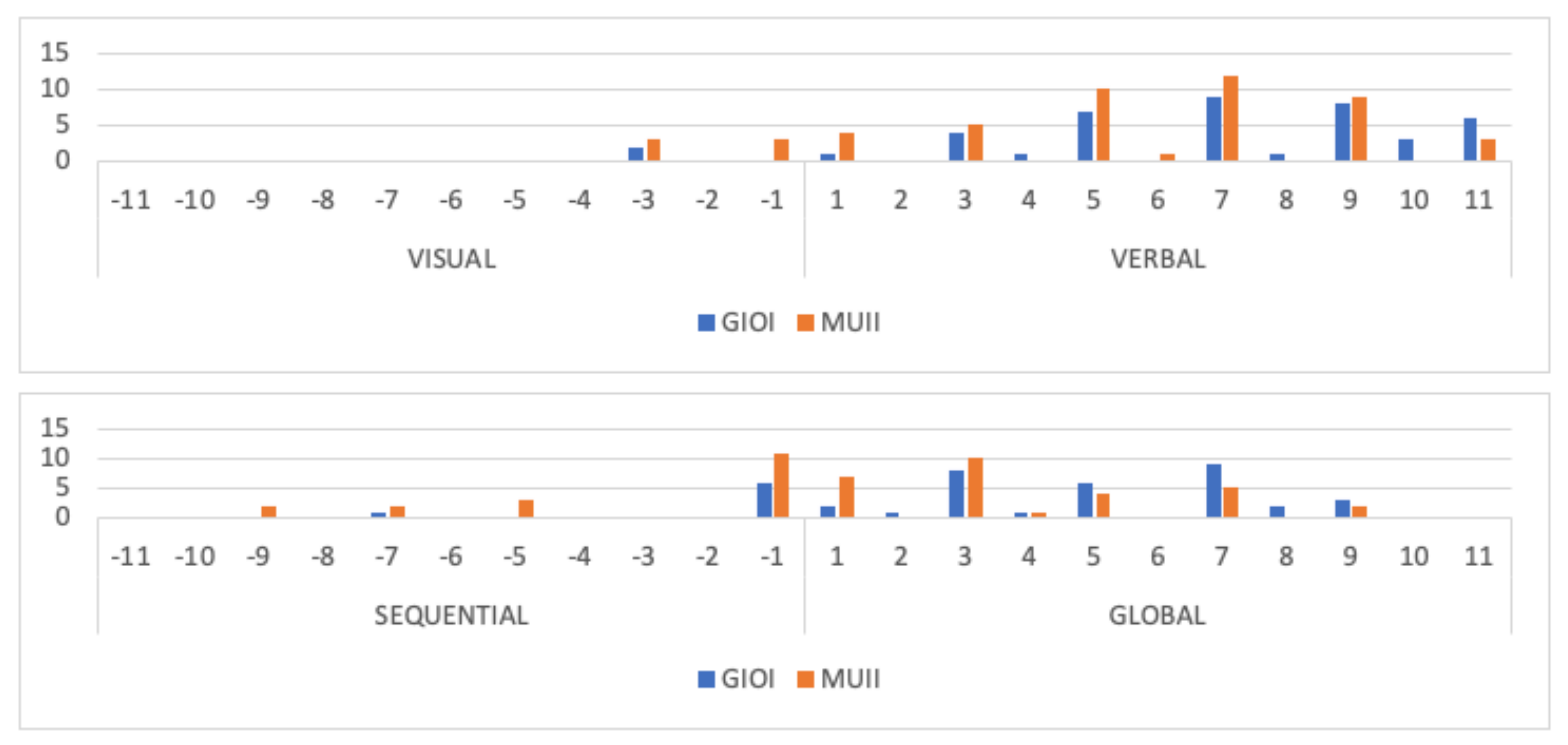

Figure 1. ILS results

The motivation of the students and the follow-up of the classes is different depending on their revealed preferences with respect to the learning styles. Lecturers must take into account the distribution within the classroom of students in their respective dichotomous positions (active-reflexive, sensitiveintuitive, visual-verbal and sequential-global). Their interest, connection in teamwork and level of acquisition of competencies will be affected if there is a large gap. Long-term performance and interaction with lecturers and other students may also be affected.

The results do not show considerable differences among Degree in Industrial Organization Engineering and the Master's Degree in Industrial Engineering students.

\section{CONCLUSIONS}

Following the results offered by the IFS, the teaching staff has important references on the learning preferences of the students and their relative weight within the group.

In addition, in a detail perspective, the learning style profile of each student provides indications of their possible strengths and opportunities which lecturers can take advantage of.

Next lines of research should study differences in learning preferences between men and women and between different types of degrees.

Lecturers must deepen the search for teaching actions that connect more with their students from the dimension of innovation, increasingly demanded by companies.

Other lines of research should guide their action to assess how preferences are related to learning styles, with lecturer's styles and with academic performance.

\section{REFERENCES}

[1] M. E, Cano, "La evaluación por competencias en la educación superior". Revista de curriculum y formación de profesorado, 2008, vol. 12, nº 3, p. 1-16, 2008.

[2] S. Martínez de Miguel, "Una experiencia de innovación del portafolio del alumno en la diplomatura de educación social, desde el marco de la educación superior en Europa". Educatio Siglo XXI, 25, pp. 125-144, 2007.

[3] J. Cabero-Almenara \& V. Marín-Díaz, "Posibilidades educativas de las redes sociales y el trabajo en grupo. Percepciones de los alumnos universitarios", Comunicar: Revista Científica de Comunicación y Educación, 21(42), pp. 165-172, 2014. http://dx.doi.org/10.3916/C42-2014-16. 
[4] M. Guitert \& M. Pérez-Mateo, "La colaboración en la red: hacia una definición de aprendizaje colaborativo en entornos virtuales" en Teoría de la Educación 14(1), pp. 10-31, 2013.

http://gredos.usal.es/jspui/bitstream/10366/121846/1/La_colaboracion_en_la_red_hacia_una_defi .pdf

[5] S. Olmos-Migueláñez, F. Martínez-Abad, E. M. Torrecilla-Sánchez \& J. J. Mena-Marcos, "Análisis psicométrico de una escala de percepción sobre la utilidad de Moodle en la universidad", RELIEVE, v. 20 (2), art. 1, 2014.

[6] S. Beck, "The teacher's role and approaches in a knowledge society", Cambridge Journal of Education, 38(4), 465-481, 2008.

[7] L. Canós-Darós; P.I. Vidal-Carreras; J.P.García-Sabater; C. Santandreu-Mascarell, "Is there a relationship between the lecturer's learning style and methodologies used in teaching? Some reflections", 12th International Technology, Education and Development Conference - INTED 2018, marzo, Valencia, 2018.

[8] A. Barbosa Da Silva; A. L. Lima De Araujo Coelho; M. R. Perelló Marín, C. Santandreu-Mascarell, "Estilos y estrategias de aprendizaje: un estudio comparativo entre España y Brasil", XXXII AEDEM Anual Meeting, junio, Gandia, 2018.

[9] C. C. Silva.; M. Candeloro; M.C. Lima, M.C., "Estratégias de ensino orientadas pelos estilos de aprendizagem dos estudantes de graduação em Administração", Encontro da Associação de Pós-Graduação em Administração e Contabilidade, 37, Rio de Janeiro. Anais... Rio de Janeiro: Anpad, 2013.

[10] A. Freiberg Hoffmann, R. Ledesma, M. Fernández Lipporace, "Estilos y estrategias de aprendizaje en estudiantes universitarios de Buenos Aires", Revista de Psicología, Vol. 35, No. 2, pp. 535-573, 2017.

[11] D.A. Kolb, "Experiential Learning: experience as the source of learning and development", Englewood Cliffs, Prentice-Hall, 1984.

[12] R.M.Felder, "How students learn: Adapting teaching styles to learning styles", Frontiers in Education Conference Proceedings, 489-493, 1988.

[13] M. Reynolds (1995). "Learning Styles: A Critique". Management Learning. Vol. 28, No. 2, pp. 115133, 1988

[14] R. M. Felder \& R. Brent, "Effective strategies for cooperative learning". Journal of Cooperation \& Collaboration in College Teaching, 10(2), pp. 69-75, 2002.

[15] T. Vallet-Bellmunt, P. Rivera-Torres, I. Vallet-Bellmunt \& A. Vallet-Belmunt, "Aprendizaje cooperativo, aprendizaje percibido y rendimiento académico de la enseñanza de marketing" en Edu-cación XX1, 20(1), pp. 277-297, 2017.

[16] R. M. Felder y B. A. Soloman, "Index of Learning Styles", 1996. Retrieved from http://www4.ncsu.edu/unity/lockers/users//felder/public/LSpage.html

[17] B. A. Soloman \& R.M. Felder, "Index of learning styles questionnaire", NC State University, 2005. Available online at: http://www. engr.ncsu.edu/learningstyles/ilsweb.html (last visited on 14.05. 2010), 70. 